\title{
Tracing post-communist urban restructuring: Changing centralities in central and eastern European capitals
}

Rapid political and economic changes after the collapse of communism led to dynamic processes of urban restructuring in cities, replacing old patterns and models of growth with ones in which capital and the market economy were central to growth and development. The transformation towards a market economy and the reintroduction of land ownership required the establishment of a new and decentralised decision-making system, with direct consequences for cities' structure and form. As part of these urban transformations, there were clear changes in location patterns of retail structures in cities, illustrating diverse patterns of post-communist cities' spatial organisation. This article explores and provides insight into some special features of this transformation, both before and after the collapse of communism, in Bucharest, Budapest, Prague and Sofia. Examining these cities offers an overview of post-communist spatial restructuring processes and explores their changing centralities, which ultimately led to fragmented cities and disintegrated urban fabric. This comparative study also outlines how different development patterns can arise in cities that shared a similar past.

Keywords: centralities, decentralisation, fragmentation, peripheries, post-communist cities 


\section{Introduction}

The sudden transition from communism had a strong impact on the dynamics and intensity of urban development in most central and eastern European cities. The reintroduction of ownership and privatisation were central factors that contributed to cities' spatial restructuring (Harloe, 1996; Nedovic-Budic et al., 2006; Stanilov, 2007; Hoxha et al., 2014; Tsenkova, 2014). The urban crisis that occurred as a result of this restructuring was continuous evolution and adaptation; it was not limited only to urban developments, but also involved broader political and socioeconomic aspects (Koželj, 1992). These processes resulted in complex urban transformations, affecting employment, the housing market, investment and demographics in cities.

The growth of cities under communism resulted in territorial expansion, but less physical change was seen in city centres (Musil, 1993). The urban transformations of post-communist cities reinforced these trends of spatial dispersion; cities continued to expand on their outskirts, further contributing to suburbanisation and peripheral development as a particular aspect of urban growth (Koželj, 2007). This suburbanisation was shaped by political and economic factors (Kok \& Kovacs, 1999), and the growth of the urban fringes and the outllow of people to the periphery in cities in transition commenced shortly after 1990. The formation of a market economy, the growing interests of real estate developers and the planning initiatives of the municipalities neighbouring the capitals resulted in the emergence of low-density neighbourhoods with single-family homes, which was a desirable housing choice for many (Leetmaa \& Tammaru, 2007). These new settlement patterns impacted not only the housing market in cities, but also the social and spatial segregation of the city and its demographics. The emergence of informal settlements in the same period contributed further to problems of social exclusion, housing provision and spatial planning (Tsenkova, 2010; Mandič \& Filipovič Hrast, 2015).

In parallel with these spatial restructuring processes, the city centre was losing its housing function, becoming more of an attraction than a living space (Kádár, 2013). At the same time, the periphery gained appeal through commercial activities introduced to accommodate local residents' needs. As a result, the transformation of retail structures in cities emerged as a central aspect of the transformation (Sykora, 1998; SailerFliege, 1999; Hirt \& Kovachev, 2006; Stefanovska \& Koželj, 2012). In this context, the periphery proved to be a better location for these new programmatic structures, adding new appeal to new parts of the city. The new centralities, or places where large agglomerations of offices and commercial buildings are located, concentrated consumer services and created new forms of urban entities. Although peripheral, these new centralities were not separate from the old city centre; they coexisted with them, which was possible in part because of the increased connectivity between the city centre and its outskirts.

New decision-making processes in post-communist planning certainly facilitated these changes, ultimately transforming the urban landscapes and the perception of cities. The changes in urban planning were a fundamental drive for the spatial transformations in cities. Planning became a developer- and market-driven process, which was often too difficult to control, further contributing to the crisis in planners' legitimacy (Kos, 2010). Furthermore, the centralised planning system under communism was replaced with a decentralised one, giving power to local government through a series of legislative changes, contributing to spatial disorder and uneven urban development (Tsenkova, 2011).

This article reports on the location patterns of centralities as part of the urban restructuring of post-communist European cities. The term centrality refers to a concentration of commercial activities and central city functions that draw large amounts of people to a certain location. A comparative study was carried out to analyse the characteristics, evolution and the location patterns of centralities built before and after the collapse of communism in Bucharest, Budapest, Prague and Sofia.

The main objective is to highlight the spatial restructuring of cities, drawing relationships among the location patterns of centralities, urban planning processes and their dynamics. Studying these aspects contributes to a better understanding of urban transformation processes after the collapse of communism, emphasising spatial restructuring through changing centralities. The central research questions are: What are the location patterns of centralities in these cities before and after communism? What drove the emergence of centralities in the post-communist context?

Section one briefly reviews urban transformation in central and eastern European capitals. Section two examines spatial restructuring and centralities built under communism in the four cities by studying their location patterns. Section three outlines some aspects of post-communist urban transformations by studying emerging centralities and location patterns. The final section offers concluding remarks on the changing centralities and their location patterns before and after the change, outlining similarities and differences in their dispersion patterns. 


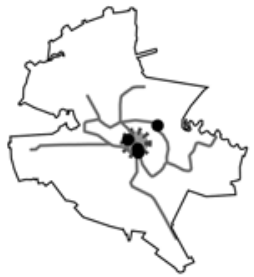

a

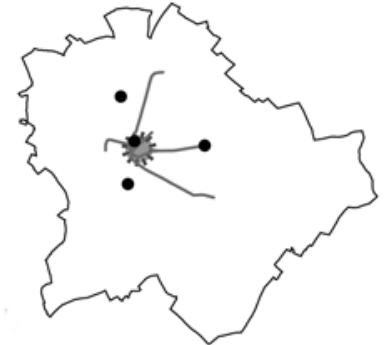

b

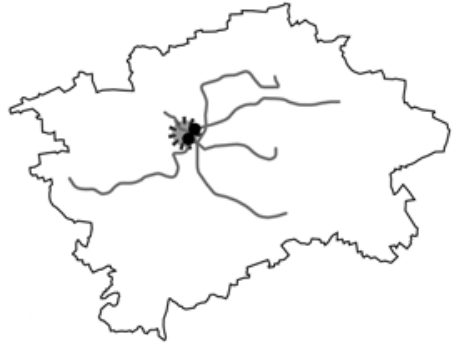

C

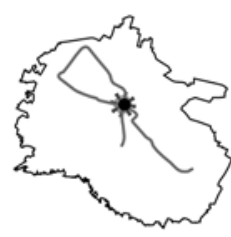

d

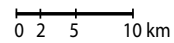

Figure 1: Centralities built before 1989 in a) Bucharest, b) Budapest, c) Prague and d) Sofia (illustration: Jasna Mariotti).

Note: All cities are shown at the same scale and their current administrative and planning area is outlined. These drawings also show the current metro lines in these cities, their historical city centres and the centralities built under communism.

\section{Spatial restructuring of cities under communism}

Under communism, cities developed growth patterns as a result of the centralised organisation of the state. Under such organisation, a distinctive feature of cities was the abolition of private ownership (Szelenyi, 1996; Musil, 2005), which fundamentally influenced cities' planning and development.

During this period, the share of urban population grew and capital cities increased in population. This was a result of the urbanisation policies and strategies of the communist organisation of the state, which included comprehensive planning and distribution of industries in cities - an integral element in the development of communist societies (Musil, 1980). Under communism, Bucharest grew by $312 \%$ and Sofia by $228 \%$, and Prague and Budapest grew by $129 \%$ and $123 \%$, respectively (World population prospects, 2008). To accommodate these growing populations, housing estates were built on the cities' outskirts, resulting in larger urban territories and fundamentally different spatial configurations. Prefabricated construction accelerated peripheral development, creating high-density neighbourhoods and alleviating housing shortages. The absence of a property market and the existence of a centrally controlled planning system impacted urban development patterns, making these transformations possible.

Urban planning was reduced to fulfilling centrally coordinated state ideologies (Maier, 1998; Golubchikov, 2004). During this period, urban planning operated in a system in which the land was nationalised and the central governments were responsible for decision-making at all levels, ultimately leading to highly controlled urban development. As a result, planning decisions made at the central level were intended to shape a concept of centralities that was based on ideas of a city with secondary and tertiary centres. Nevertheless, these visions were almost never realised because throughout the period the main focus was on housing in cities, accommodating their population growth and increasing urbanisation at the national level. Such decisions were critical in establishing a monocentric city with a strong centre that housed all the city's functions.

The communist-era retail centres in Bucharest, Budapest, Prague and Sofia were either closely linked to the city centres or in them (Figure 1). Their location was state-controlled and, like other urban properties, they were also state-owned. The four cities illustrate localised dispersion patterns of centralities built before 1989, which were very few and limited in number, and were located close to the topographical and historical city centres. As a result of these trends, the consumer patterns in these cities were also localised and highly controlled, together with goods sold in them. Nevertheless, the buildings were masterpieces of communist architecture and thinking (Figure 2).

The Kotva department store built in Prague between 1966 and 1974 was the first department store built under communism in Prague (Figure 2c). When completed, it was also the largest department store in Czechoslovakia. Kotva exemplified communist architecture, built from hexagonal prisms stacked on top of each other, and its dynamic façade is an outstanding example of brutalism. The building was built using raw industrial materials such as iron, glass and concrete and, although located in the city's historic neighbourhood, its complex structure stands out boldly. Shortly after its opening, the building became a city icon and the building now has protected status. The second department store built under communism in Prague was My on National Avenue (Národni trída). Built in 1978, My is also a prime example of 1970s Czech architecture and also has protected status. Unlike 

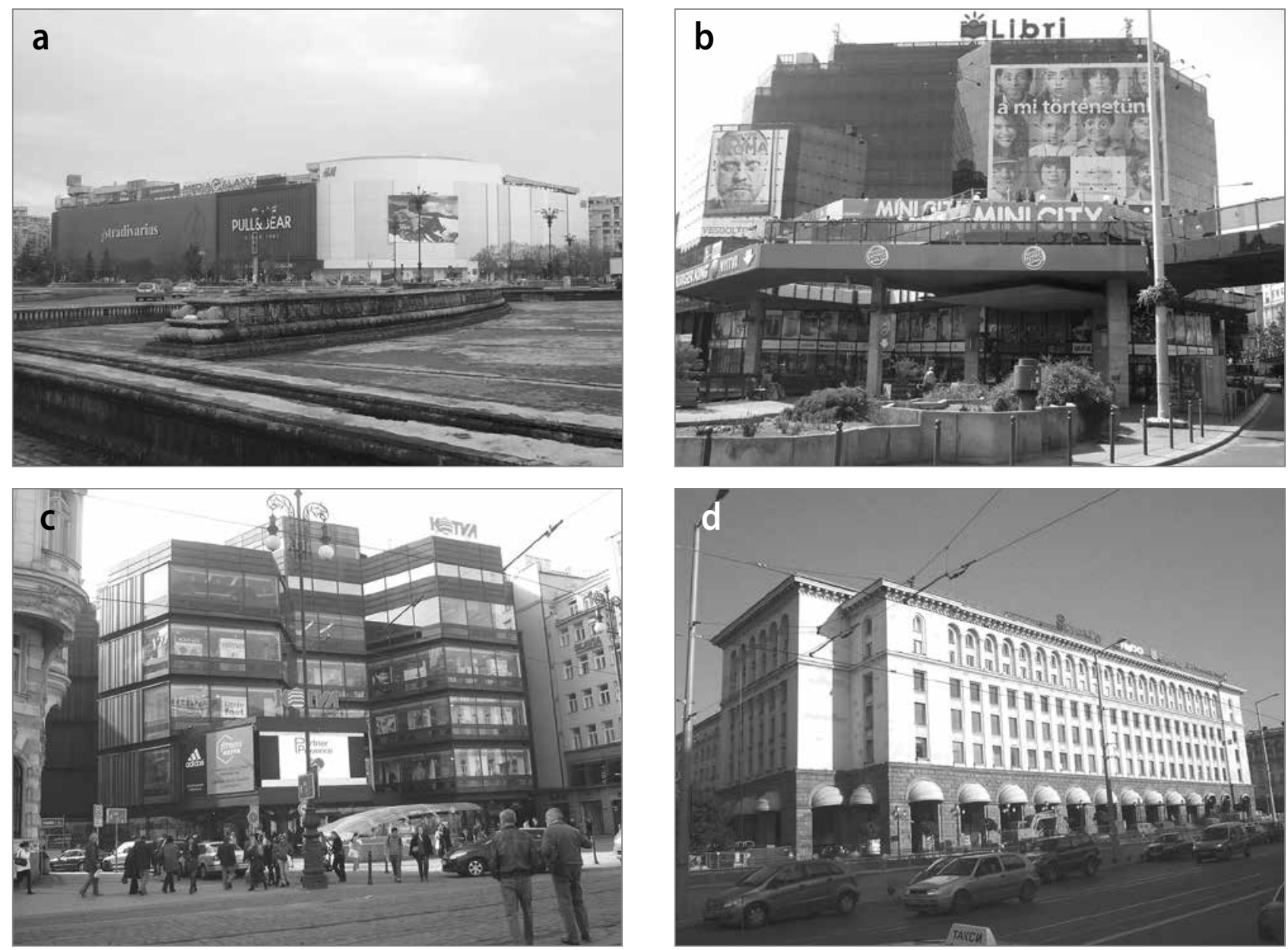

Figure 2: Centralities built before 1989 in a) Bucharest, Unirea, 1976 (1989), b) Budapest, Skala Metro, 1984, c) Prague, Kotva, 1966-1974, and d) Sofia, Central Department Store, 1957 (2000) (photo: Jasna Mariotti).

Kotva, its structure is rather simple and linear, but it still has outstanding qualities. The Unirea shopping centre in Bucharest (Figure 2a), built in 1976 and expanded in 1989, was the largest department store in communist Romania. Although this Romanian shopping centre was built in the city centre and on Union Boulevard (Bulevardul Unirii), a powerful axis created to accommodate Ceauşescu's grandeur vision for $\mathrm{Bu}-$ charest, Unirea does not share the character of the surrounding buildings. It was nevertheless an influential example of Romanian consumerism in both its size and appearance. The original Unirea building had large windows, but these cannot be seen today because they are covered by billboards, which make the original structure barely visible. The Central Department Store in Sofia opened in 1957 and was a monument of communist consumerism in Bulgaria (Figure 2d). It was built on one of the city's main axes and it is a monumental building symbolising Sofia's modernisation, dominating the city centre with its size and footprint. Although they have been transformed and sometimes expanded, these shopping centres are still a powerful presence in the urban fabric of Bucharest, Budapest, Prague and Sofia; their appearance and authoritative footprints docu- ment patterns of communist consumerism in a city meant for socialist men.

\section{Post-communist urban restructuring: Changing centralities}

The urban transformations of post-communist cities are a result of complex social, economic, cultural and political changes. At the background of these processes was privatisation (Stark, 1992; Clapham, 1995; Markuse, 1996; Grime, 1999; Stanilov, 2007; Sendi, 2013), or property restitution, which changed the market and, arguably, conditions for urban development. These transformation processes resulted in the triumph of neoliberalism in post-communist cities' development patterns (Sailer-Fliege, 1999; Smith \& Rochovska, 2007; Golubchikov \& Phelps, 2009). The post-communist transformation of Bucharest, Budapest, Prague and Sofia took place through densification of the urban fabric and was achieved through a continual increase in homes, offices, and shopping centres. 
Table 1: Housing stock per 1,000 inhabitants in Bucharest, Budapest, Prague and Sofia.

\begin{tabular}{llll}
\hline City & 1991 & 2001 & 2011 \\
\hline Bucharest & n/a & 396 & 411 \\
\hline Budapest & 396 & 466 & 516 \\
\hline Prague & 424 & 473 & $\mathrm{n} / \mathrm{a}$ \\
\hline Sofia & 409 & 437 & 471 \\
\hline
\end{tabular}

Source: Czech Statistical Office in Prague (1990-2011), Hungarian Central Statistical Office in Budapest (1990-2011), National Statistical Institute in Sofia (1990-2011) and National Institute of Statistics in Bucharest (1990-2011).
Table 2: Average members per census household in Bucharest, Budapest, Prague and Sofia.

\begin{tabular}{lll}
\hline City & 1991 & 2011 \\
\hline Bucharest & $2.8(1995)$ & $2.6(1999)$ \\
\hline Budapest & $2.2(2006)$ & $2.3(2009)$ \\
\hline Prague & 2.2 & 2.1 \\
\hline Sofia & 2.5 & 2.2 \\
\hline
\end{tabular}

Source: Czech Statistical Office in Prague (1990-2011), Hungarian Central Statistical Office in Budapest (1990-2011), National Statistical Institute in Sofia (1990-2011) and National Institute of Statistics in Bucharest (1990-2011).

Table 3: Building permits issued in Bucharest, Budapest, Prague and Sofia.

\begin{tabular}{lllllll}
\hline City & 2000 & & 2005 & & 2010 & \\
\hline & Residential & Non-residential & Residential & Non-residential & Residential & Non-residential \\
\hline Bucharest & $\mathrm{n} / \mathrm{a}$ & $\mathrm{n} / \mathrm{a}$ & 1,254 & 244 & 833 & 136 \\
\hline Budapest & 1,737 & 377 & 1,377 & 152 & 811 & 84 \\
\hline Prague & 7,761 & 2,383 & 7,485 & 1,832 & 4,819 & 1,783 \\
\hline Sofia & $\mathrm{n} / \mathrm{a}$ & $\mathrm{n} / \mathrm{a}$ & 1,226 & 387 & 596 & 205 \\
\hline
\end{tabular}

Source: Czech Statistical Office in Prague (1990-2011), Hungarian Central Statistical Office in Budapest (1990-2011), National Statistical Institute in Sofia (1990-2011) and National Institute of Statistics in Bucharest (1990-2011).

Since the collapse of communism, the housing stock in the four cities has been constantly increasing (Table 1). The continually growing numbers of homes in these cities infilled empty areas, although their populations in the same period changed at a different pace. Between 1990 and 2010, Bucharest's population decreased by $8.59 \%$ and Budapest's population decreased by $14.7 \%$. The populations of Prague and Sofia increased by $2.95 \%$ and $9.47 \%$, respectively, despite the larger increase in their housing stocks. These two different dynamics - the housing stock and the city's population - spatially disrupted the urban fabric of the four cities. In part, these transformations also resulted from the decreasing size of households in these cities (Table 2).

In Bucharest, the average members per census household decreased from 2.8 to 2.6 from 1995 to 1999, in Prague from 2.2 to 2.1 from 1991 to 2011 and in Sofia from 2.5 to 2.2 in the same period. Budapest was an exception: the average increased (from 2.2 to 2.3 between 2006 and 2009, which is the only period for which data are available); however, at the national level in Hungary that number is stable in the same period, at 2.6.

Parallel to these records of decline, the construction activities in these cities declined as well, as seen in the building permits issued between 2000 and 2010 in the four cities according to data from the national statistical offices from these cities (Table 3). However, there are differences among the building permits issued for residential and non-residential build-
Table 4. Ratio between population and cars in Bucharest, Budapest, Prague and Sofia.

\begin{tabular}{llll}
\hline City & 1990 & 2000 & 2005 \\
\hline Bucharest & $8.16^{*}$ & 5.01 & 4.34 \\
\hline Budapest & 4.28 & 3.20 & 2.84 \\
\hline Prague & 4.14 & 1.90 & 1.95 \\
\hline Sofia & n/a & 2.90 & 2.00 \\
\hline
\end{tabular}

Note: * Data are available for 1991.

Source: Czech Statistical Office in Prague (1990-2011), Hungarian Central Statistical Office in Budapest (1990-2011), National Statistical Institute in Sofia (1990-2011) and National Institute of Statistics in Bucharest (1990-2011).

ings among these cities. For example, in Prague in 2010 the building permits for non-residential buildings corresponded to $36.9 \%$ of the residential ones, and the situation was similar in Sofia in 2005 and 2010, when the building permits for non-residential buildings corresponded to $31.5 \%$ and $34.3 \%$ of the residential building permits. Lower percentages between the non-residential and residential building permits are noted in Bucharest and in Budapest, resulting in higher numbers of residential buildings than non-residential ones, despite the declining demographics during the same period.

In addition to these building initiatives, major spatial restructuring occurred in Bucharest, Budapest, Prague and Sofia. This restructuring resulted from the emergence of centralities: places of greater economic agglomeration that were different in appearance and locality from those built under communism. In 


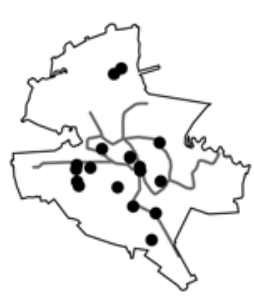

a

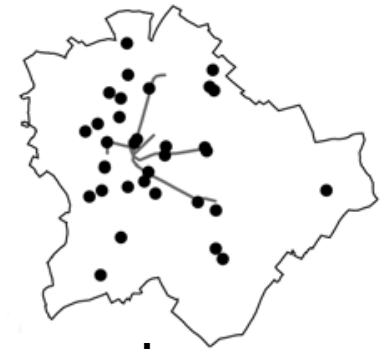

b

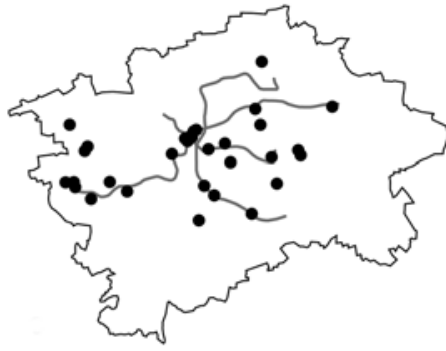

C

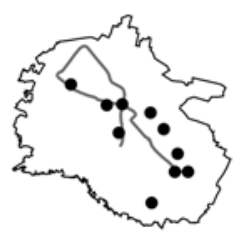

d

Figure 3: Centralities built after 1989 in a) Bucharest, b) Budapest, c) Prague and d) Sofia (illustration: Jasna Mariotti).

Note: All cities are shown at the same scale and their current administrative and planning area is outlined. These drawings also show the current metro lines in these cities and centralities in the form of new post-communist shopping centres.

the post-communist context, the new centralities, in the form of shopping centres, are guiding the spatial restructuring of the urban fabric, dominated by landscapes of consumption (Zukin, 1991). The changing patterns and localities of centralities are a feature of a city in transition (Garb \& Dybicz, 2006), and the diversity of the consumption patterns is one of the most significant characteristics of cities after the collapse of communism (Sailer-Fliege, 1999; Kreja, 2006). Under such conditions, in post-communist contexts the retail environments in cities have changed and the geographical constraints that existed during communism were relaxed due to increased accessibility and mobility (Rosu \& Blăgeanu, 2015).

The new retail structures in post-communist cities have different spatial arrangements and follow a different location logic, appearing in clusters or as isolated entities near metro lines; where these were unavailable, new metro stops were planned and built. Most post-communist centralities were also positioned next to highway exits because cars were the best way to access them. As a result, the four cities saw a dramatic increase in the number of vehicles after 1989, which at present is among the highest in Europe (Table 4). In Bucharest, the ratio between the population and cars declined from 8.16 to 4.34 between 1991 and 2005, and in Budapest from 4.28 to 2.84 in the same period. In Prague it declined from 4.14 to 1.95 between 1990 and 2005, and in Sofia from 2.9 to 2.0, resulting in pressure on the cities' infrastructure and frequent traffic congestion. Sofia now has one of the highest shares of cars among European capitals, with 546 cars per 1,000 people, compared to Vienna (397 cars per 1,000), London (331), Berlin (319) and Madrid (437; Sofia in figures, 2009: 8). The volume of cars in Bucharest increased by $71 \%$ between 1991 and 2005, greatly contributing to pollution in the city; Bucharest is in fact the second-most polluted capital in Europe, immediately after Sofia (Romania Insider, 2012).
The emergence of centralities in Bucharest, Budapest, Prague and Sofia after 1989 illustrates patterns of diverse intensification of functions within their urban fabric, and it also shows the rise of new centres outside the historical city centre (Figure 3). The decentralisation of retail activities, also described as a "retail revolution" (Garb \& Dybicz, 2006), was a salient phenomenon of post-communist cities. These peripheral developments were made possible through increased connectivity, accessibility and interaction between the outskirts and the traditional city centre, blending together or obscuring the existing hierarchical levels (Stefanovska, 2014). The expansion of the new centralities occurred gradually because in the early 1990s small shops emerged, especially in the former communist housing estates. Shortly after, large shopping malls started to appear in these cities, each new one attempting to compete in size with ones previously built, therefore creating an exponential growth trend. Budapest and Prague are leading this process of de-centering through new shopping centres; in Bucharest and in Sofia, the number of shopping centres is projected to increase after the economic downturn is over.

Regardless of this intensified development, the architecture of post-communist shopping centres, each seeking to be larger than the previous, is highly generic. This contrasts with communist architectural precedents in the four cities, which were pioneers in construction and maintained some humane aspects of shopping. Currently, prefabricated boxes filled with commercial activities are being built rather quickly, not exhibiting any contextual understanding or qualities, but solely a commercial grandeur (Figure 4).

Despite these growth trends, recently there have been attempts to control the rapid and abundant emergence of new shopping centres in Budapest through the Plaza Stop law, a first effort towards controlling commercial developments. The Plaza Stop law is an alteration of the 1997 General Law on modifying 

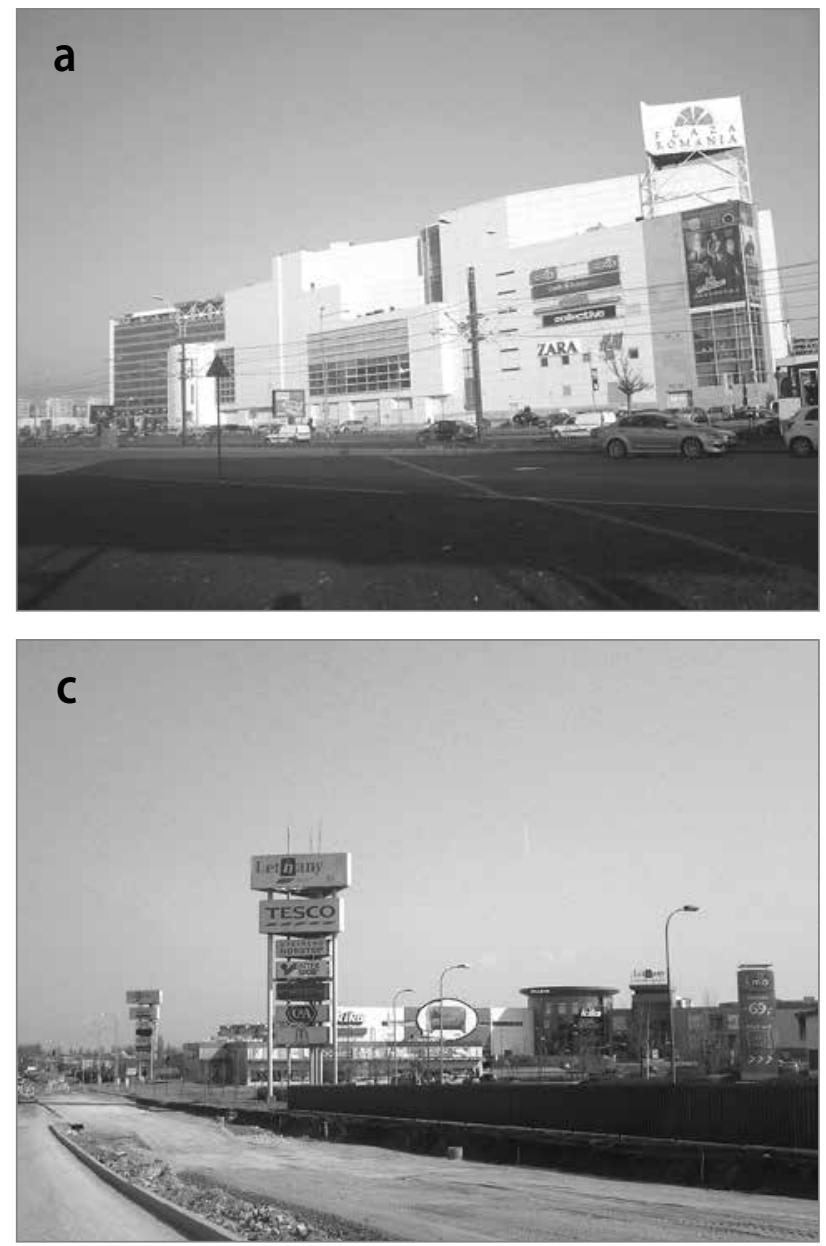
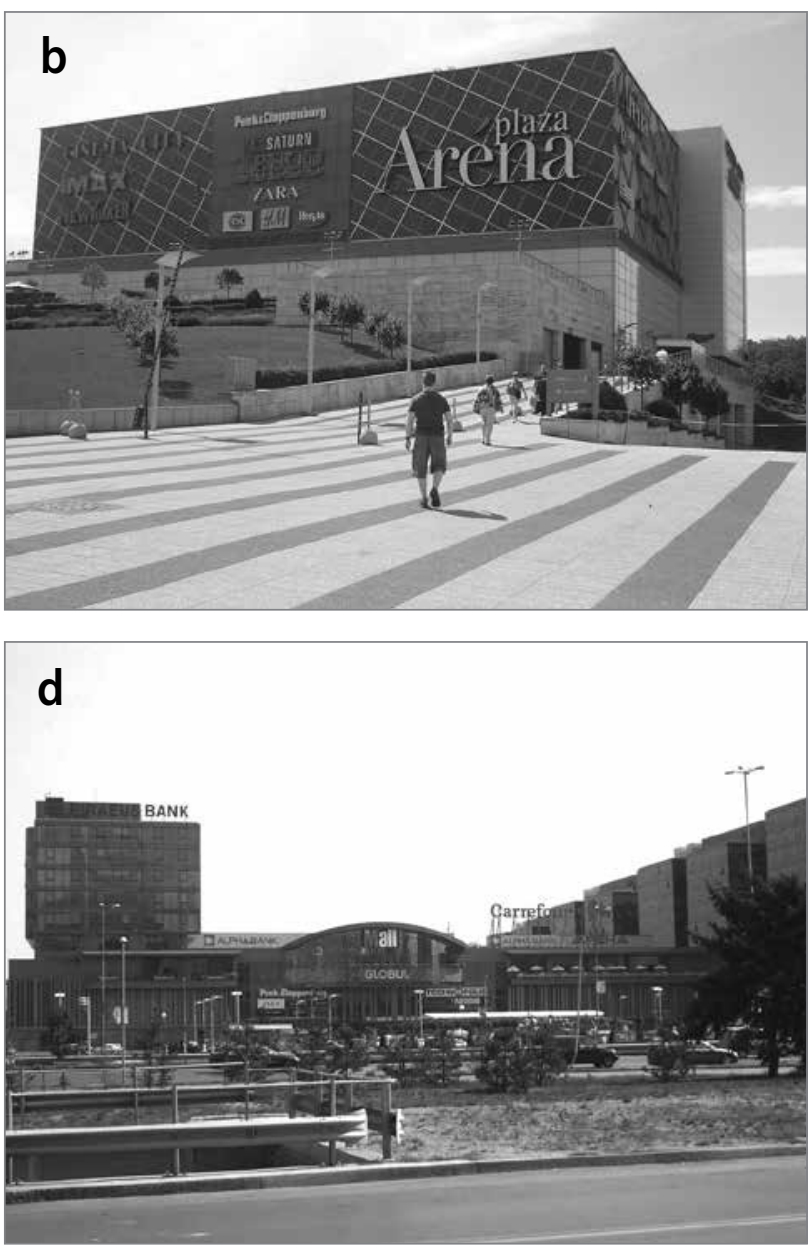

Figure 4: Centralities built after 1989 in a) Bucharest, Plaza Romania, 2005, b) Budapest, Arena Plaza, 2007, c) Prague, Letnany, 1999, and d) Sofia, Mall, 2010 (photo: Jasna Mariotti).

and protecting the built environment. According to the latest changes, it is forbidden to build commercial buildings larger than $300 \mathrm{~m}^{2}$. Expansions of current commercial buildings are also prohibited, but exemptions are possible and personal approval of the minister of economic affairs is needed in such cases. The Plaza Stop law was in effect from January 1st, 2012 until the end of 2014; the results of such legislative changes are yet to be seen.

In parallel with these trends of control over peripheral developments, there have also recently been attempts to revitalise the inner city areas of Bucharest, Budapest, Prague and Sofia. Since 2010, in Bucharest there has been an inner city gentrification through the introduction of commercial activities to the central city area, which was overlooked in the communist period. The Urban Renewal Programme was approved by the General Assembly of Budapest in 1997 and aimed at "providing a means of renovating buildings, infrastructure and public space, along with improving the urban fabric" (Municipality of Budapest, 2002: 3). As a result of this programme, Budapest approved eleven target areas to be considered in the programme; the revitalisation centred on the most derelict neighbourhoods in the city and specified measures for each urban district. In Prague, urban renewal took place through regeneration of former industrial sites in the inner city. One of those areas, Karlin, was heavily damaged by floods over two meters deep in 2002. Although earlier attempts to redevelop it started even before the floods, the area emerged as a place for investment that accelerated immediately afterwards. Karlin is located on the banks of the Vltava River and is a pioneering project for regenerating industrial areas through commercial and office redevelopment (Sykora, 2007). In Sofia, inner city renewal is driven by the largest public intervention in the city, the construction of the metro, an idea that started under communism. The full effects of metro construction on the city centre are yet to be seen.

\subsection{Post-communist urban planning in Bucharest, Budapest, Prague and Sofia}

After the collapse of communism, the four cities maintained their old planning boundaries, with minor changes only in 
Bucharest and Sofia in recent years. In Prague, the planning and administrative boundary was established in 1974, and in Budapest in 1950. Nevertheless the spatial structure of these cities changed dramatically because the city was moving from being industrial- and production-oriented towards a post-industrial city, which is service- and commerce-driven. Because post-communist urban planning was introduced in these cities, its institutional base changed (Maier, 1998). Despite the early enactment of planning and building acts in these cities, the first master plans were adopted rather late, illustrating the increased bureaucracy of planning processes in post-communist contexts. In Prague, the latest plan adopted under communism was from 1986. This plan was revised in 1994; however, the first new plan after 1989 was adopted in 1999 (Cz. Územni Plán blavníbo mèsta Praby). The planning initiatives for a new masterplan in Bucharest started in 1994 and the first plan after the collapse of the Ceauşescu regime was approved in 2000 (Rom. Planul Urbanistic General). In Budapest, the first plan after 1989 was adopted in 2005 (Hung. Altalános rendezési tervének), although the preparatory processes started in 1997 and were followed by a public discussion in 1998. A decision to produce a new plan for Sofia (Bulg. Obš ustrojstven plan), one to guide the transformation processes after 1989, was made in 1990. Nevertheless, the first plan after 1989 in Sofia was approved only in 2009. Because these plans were adopted rather late, they had to deal with ongoing construction activities in these cities and privatisation processes at an advanced stage. In addition to master plans, which were made for the entire urban territory and are in fact land-use plans, planning at the local level is also present. These planning initiatives were adopted and guided by local government, which was given the responsibility to conduct planning and issue building permits as part of decentralising the planning processes. Currently there are differences among the four cities depending on the sub-dimensions of decentralisation (Stefanovska, 2014). Nevertheless, post-communist building permits for new centralities show decentralisation of the governing structure and changing competences at different levels of decision-making in the cities. In addition, the post-communist decentralisation of retail activities ultimately resulted in a different city than the one that existed only twenty years earlier, even though twenty years is a short period in urban history.

\section{Conclusion: The making of a post- -communist European metropolis}

This article examined the urban transformation of postcommunist cities based on the emergence of centralities in Bucharest, Budapest, Prague and Sofia, and it highlighted the differences and similarities in their location patterns. It also shows that there was a proliferation of consumerism and powerful reshaping of urban landscapes after the collapse of communism, which also symbolised the democratisation of the decision-making processes in these cities. These changes resulted in an intense flow of people around these newly established economies in the four cities. In parallel, the concept of the city centre lost its traditional meaning over the years and shifted from being a centre of civic and religious activities and a place with concentration of political power to a place where business is dominant.

Through the decentralisation of post-communist governing processes, decision-making in the four cities was transferred to local government. Transformation of the retail structure in these cities was no longer part of planning at a city level, but devolved to local government, creating a complex model of interplay between urban planning and politics at different levels of decision-making.

The similarities among these cities after the fall of communism are shown by the proliferation of new retail structures built in only twenty years, which were numerous and generic in their appearance. The differences among them are shown by the retail units' growth dynamics and intensity. More importantly, the dispersion patterns are not the same in these cities; the pattern of peripheral dispersion in Budapest is more evident than that in Prague, and in Bucharest it is closely tied to the metro system. In Sofia, the dispersion model follows the east-west city axis. These differences result from different cultural identities, but more importantly from the decentralisation characteristics and governing differences in these cities after communism, which argues for a contextual approach to studying this topic.

The newly emerged centralities are fundamental for understanding the spatial restructuring of cities after communism. The different models of growth dynamics and dispersion patterns of centralities emerged in just over twenty years; they were limited and localised under communism, and dispersed and augmented after communism. After 1989, the shift of centralities towards the peripheries of Bucharest, Budapest, Prague and Sofia contributed to a rediscovery and formation of a polycentric city model, releasing the pressure of development in historic city centres and providing more equal distribution of resources. The extension of public transport networks and increased mobility facilitated these dispersion patterns, optimising building activities and adding diverse urban functions throughout these resilient post-communist cities.

The changing patterns of centralities and the emergence of new spaces for consumerism are the most obvious signs of the move towards capitalism, a liberalised market, new politics and global trends in the urban transformations after communism. 
The newly emerged centralities in the four cities are their new social spaces, enlivened with an array of social activities, contributing to the cities' urban restructuring. Although the locations of the newly emerged centralities are peripheral, they generate intense development in their surroundings and create a secondary vitality that produces a metropolitan lifestyle. Although they remain within the same city boundaries, these conditions are a fundamental driver for spatially restructuring monocentric communist cities into polycentric post-communist metropolises.

\section{Jasna Mariotti}

Queen's University Belfast, School of Planning, Architecture and Civil Engineering, Belfast, United Kingdom

E-mail: jasna.mariotti@gmail.com

\section{Janez Koželj}

University of Ljubljana, Faculty of Architecture, Ljubljana, Slovenia E-mail: janez.kozelj@fa.uni-lj.si

\section{References}

Clapham, D. (1995) Privatisation and the east European housing model. Urban Studies, 32(4-5), pp. 679-694. DOI: 10.1080/00420989550012834

Czech Statistical Office in Prague (1990-2011) Statistical yearbook of Prague. Prague.

Garb, Y. \& Dybicz, T. (2006) The retail revolution in post-socialist centra Europe and its lessons. In: Tsenkova, S. \& Nedovic-Budic, Z. (eds.) The urban mosaic of post-socialist Europe, pp. 231-252. Heidelberg, PhysicaVerlag. DOl: 10.1007/3-7908-1727-9_12

Golubchikov, O. (2004) Urban planning in Russia: Towards the market. European Planning Studies, 12(2), pp. 229-247.

DOI: 10.1080/0965431042000183950

Golubchikov, O. \& Phelps, N. (2009) Post-socialist post-suburbia? Growth machine and the emergence of "edge city" in the metropolitan context of Moscow. Paper presented at the 3rd International Workshop on Post-Communist Urban Geographies "Actors Shaping Urban Change", 17-19 September, Tartu, Estonia. Typescript.

Grime, K. (1999) The role of privatization in post socialist urban transition: Budapest, Krakow, Prague and Warsaw. GeoJournal, 49(1), pp. 3542. DOI: $10.1023 / \mathrm{A}: 1007048504472$

Harloe, M. (1996) Cities in the transition. In: Andrusz, G., Harloe, M. \& Szelenyi, I. (eds.) Cities after socialism - Urban and regional change and conflict in post-socialist societies, pp. 1-29. Oxford, Blackwell. DOI: 10.1002/9780470712733.ch1

Hirt, S. \& Kovachev, A. (2006) The changing spatial structure of post-socialist Sofia. In: Tsenkova, S. \& Nedovic-Budic, Z. (eds.) The urban mosaic of post-socialist Europe: Space, institutions and policy, pp. 113-130. Heidelberg, Physica-Verlag. DOI: 10.1007/3-7908-1727-9_6

Hoxha, V., Dimitrovska Andrews, K. \& Temeljotov Salaj, A. (2014) Cultural factors affecting urban planners' intentions to regulate public space in Prishtina, Kosovo. Urbani izziv, 25(2), pp. 76-89.

DOI: 10.5379/urbani-izziv-en-2014-25-02-001

Hungarian Central Statistical Office in Budapest (1990-2011) Statistical yearbook of Budapest. Budapest.

Kádár, B. (2013) Differences in the spatial patterns of urban tourism in
Vienna and Prague. Urbani izziv, 24(2), pp. 96-111. DOI: 10.5379/urbani-izziv-en-2013-24-02-002

Kok, H. \& Kovacs, Z. (1999) The process of suburbanization in the agglomeration of Budapest. Netherlands Journal of Housing and the Built Environment, 14(2), pp. 119-141. DOI: 10.1007/BF02496818

Kos, D. (2010) Prostorsko urejanje med stroko in piarom. Teorija in praksa, 47(2-3), pp. 413-434.

Koželj, J. (1992) O krizi urbanizma in izhodih iz nje. Urbani izziv, 19, pp. $20-25$.

Koželj, J. (2007) Opredelitev sodobnega mesta. In: Cerpes, I. \& Desman, M. (eds.) O urbanizmu: Kaj se dogaja s sodobnim mestom, pp. 195208. Ljubljana, Založba Krtina.

Kreja, K. (2006) Spatial imprints of urban consumption: Large scale retail development in Warsaw. In: Tsenkova, S. \& Nedovic-Budic, Z. (eds.) The urban mosaic of post-socialist Europe, pp. 253-272. Heidelberg, Physica-Verlag. DOI: 10.1007/3-7908-1727-9_13

Leetmaa, K. \& Tammaru, T. (2007) Suburbanization in countries in transition: Destinations of suburbanizers on the Tallinn metropolitan area. Geografiska Annaler: Series B, Human Geography, 89(2), pp. 127-146. DOI: 10.1111/j.1468-0467.2007.00244.x

Maier, K. (1998) Czech planning in transition: Assets and deficiencies. International Planning Studies, 3(3), pp. 351-365. DOI: 10.1080/13563479808721719

Mandič, S. \& Filipovič Hrast, M. (2015) Alternatives to social housing: Applicants' views of various policy options. Urbani izziv, 26(1), pp. 6982. DOI: 10.5379/urbani-izziv-en-2015-26-01-001

Marcuse, P. (1996) Privatization and its discontents: Property rights in land and housing in the transition in eastern Europe. In: Andrusz, G., Harloe, M. \& Szelenyi, I. (eds.) Cities after socialism - Urban and regional change and conflict in post-socialist societies, pp. 119-191. Oxford, Blackwell. DOI: $10.1002 / 9780470712733 . c h 5$

Municipality of Budapest (2002) Urban Renewal Programme: Budapest 2002. Budapest.

Musil, J. (1980) Urbanization in socialist countries. White Plains, NY, M. E. Sharpe.

Musil, J. (1993) Changing urban systems in post-communist societies in central Europe: Analysis and prediction. Urban Studies, 30(6), pp. 899906. DOI: 10.1080/00420989320080841

Musil, J. (2005) City development in central and eastern Europe before 1990: Historical context and socialist legacies. In: Hamilton, I. F. E., Dimitrovska Andrews, K. \& Pichler-Milanovic, N. (eds.) Transformation of cities in central and eastern Europe: Towards globalization, pp. 22-43. Tokyo, United Nations University Press.

National Institute of Statistics in Bucharest (1990-2011) Statistical yearbook of Bucharest. Bucharest.

National Statistical Institute (2009) Sofia in figures 2009. Available at: www.sofia.bg (accessed 10 Sept. 2015).

National Statistical Institute in Sofia (1990-2011). Sofia in figures. Sofia.

Nedovic-Budic, Z., Tsenkova, S. \& Marcuse, P. (2006) The urban mosaic of post-socialist Europe. In: Tsenkova, S. \& Nedovic-Budic, Z. (eds.) The urban mosaic of post-socialist Europe: Space, institutions and policy, pp. 3-20. Heidelberg, Physica-Verlag. DOI: 10.1007/3-7908-1727-9_1

Romania Insider (2012) Bucharest, second most polluted capital in Europe but ranks better then Paris on green areas, 17 May 2012. Available at: http://www.romania-insider.com (accessed 10 Sept. 2015).

Rosu, L. I. \& Blăgeanu, A. (2015) Evaluating issues and performance of a public transport network in a post-communist city using a quantitative 
spatial approach. Urbani izziv, 26(2), pp. 103-116.

DOI: 10.5379/urbani-izziv-en-2015-26-02-002

Sailer-Fliege, U. (1999) Characteristics of post-socialist urban transformation in east central Europe. GeoJournal, 49(1), pp. 7-16. DOI: 10.1023/A:1006905405818

Sendi, R. (2013) The low housing standard in Slovenia: Low purchasing power as an eternal excuse. Urbani izziv, 24(1), pp. 107-124. DOI: 10.5379/urbani-izziv-en-2013-24-01-002

Smith, A. \& Rochovska, A. (2007) Domesticating neo-liberalism: Everyday lives and the geographies of post-socialist transformations. Geoforum, 38(6), pp. 1163-1178. DOI: 10.1016/j.geoforum.2007.03.003

Stanilov, K. (2007) Taking stock of post-socialist urban development: A recapitulation. In: Stanilov, K. (ed.) The post-socialist city: Urban form and space transformations in central and eastern Europe after socialism, pp. 3-20. Dordrecht, Springer. DOI: 10.1007/978-1-4020-6053-3_1

Stark, D. (1992) Path dependence and privatization strategies in east central Europe. East European Politics and Societies, 6, pp. 17-54. DOI: $10.1177 / 0888325492006001003$

Stefanovska, J. (2014) Planning the post-socialist city: Urban transformations and changing centralities after socialism. Doctoral thesis. Ljubljana University of Ljubljana, Faculty of Architecture.

Stefanovska, J. \& Koželj, J. (2012) Urban planning and transitional development issues: The case of Skopje, Macedonia. Urbani izziv, 23(1), pp. 91-100. DOI: 10.5379/urbani-izziv-en-2012-23-01-002

Sykora, L. (1998) Commercial property development in Budapest, Prague and Warsaw. In: Enyedi, G. (ed.) Social change and urban restructuring in central Europe, pp. 109-136. Budapest, Akadémiai Kiadó.

Sykora, L. (2007) Office development and post-communist city formation: The case of Prague. In: Stanilov, K. (ed.) The post-socialist city: Urban form and space transformations in central and eastern Europe after socialism, pp. 117-145. Dordrecht, Springer.

DOI: 10.1007/978-1-4020-6053-3_7

Szelenyi, I. (1996) Cities under socialism - and after. In: Andrusz, G., Harloe, M. \& Szelenyi, I. (eds.) Cities after socialism - Urban and regional change and conflict in post-socialist societies, pp. 286-317. Oxford, Blackwell.

Tsenkova, S. (2010) Informal settlements in post-communist cities: Diversity factors and patterns. Urbani izziv, 21(2), pp. 73-84. DOI: 10.5379/ urbani-izziv-en-2010-21-02-001

Tsenkova, S. (2011) Venturing into unknown territory: Strategic spatial planning in post-communist cities. Urbani izziv, 22(1), pp. 83-99. DOI: 10.5379/urbani-izziv-en-2011-22-01-001

Tsenkova, S. (2014) The housing policy nexus and people's responses to housing challenges in post-communist cities. Urbani izziv, 25(2), pp. 90-106. DOI: 10.5379/urbani-izziv-en-2014-25-02-002

United Nations Population Division (2015) World population prospects 2008. Available at: http://esa.un.org (accessed 11 Sept. 2015).

Zukin, S. (1991) Landscapes of power: From Detroit to Disney World. Berkley, University of California Press. 